\title{
On regional security governance once again: how analysis of the Southern Caucasus can advance the concept
}

\author{
Michela Ceccorulli ${ }^{\mathrm{a}}$, Carlo Frappi ${ }^{\mathrm{b}}$ and Sonia Lucarelli ${ }^{\mathrm{a}}$ \\ ${ }^{a}$ Department of Social and Political Sciences, University of Bologna, Italy; ${ }^{b}$ Department of studies on Asia and \\ Mediterranean Africa, University of Cà Foscari, Venice, Italy
}

\begin{abstract}
Already introduced to the academic and political debate some years ago, the concept of "security governance" still needs to be clarified. In particular, four main shortcomings need to be overcome to make the concept more useful for an assessment of current security dynamics: in the first place, attention has been devoted more to "governance" than to "security", while failing to consider the role of the understandings and perceptions of the actors involved in the governance system. Second, the literature on the actors (governmental or not) involved is still fragmented. Third, the literature on security governance has too often been detached from reflections on regionalism, while it would be useful to further explore the relationship between cognitive definitions of regional and security dynamics. Fourth, the literature has predominantly focused on Europe and the transatlantic area, overlooking processes of "region-building" in security terms in other "unexpected" geographical spaces. After proposing avenues to overcome the current gaps in the literature, the Southern Caucasus is chosen as a case study to show the different instances of security governance emerging, thanks to definitions of the region in security terms that have involved regional and external actors, of a state and non-state nature.
\end{abstract}

\section{ARTICLE HISTORY}

Received 16 June 2016

Accepted 21 October 2016

\section{KEYWORDS}

Regional security

governance; Southern

Caucasus; regionalism; private security actors; perceptions; region-building

\section{Introduction}

Broadly speaking, the concept of "security governance" refers to an "intentional system of rule that involves the coordination, management and regulation of issues by multiple and separate authorities, interventions by both public and private actors, formal and informal arrangements and purposefully directed towards particular policy outcomes" (Kirchner and Sperling 2007, p. 3). The literature, however, varies quite a lot as to the type of "authorities" (states, private actors, and international organisations), type of coordination (formal or informal arrangements), and the policy areas to which it is applied (traditional security issues or a wider understanding of what security is). In other words, the concept is flexible enough to capture most of the new features characterising the governance of specific issues and regarding both the actors and the levels of cooperation at play. James Sperling sees it as

CONTACT S. Lucarelli sonia.lucarelli@unibo.it 
a heuristic device for recasting the problem of security management in order to accommodate the coexistence of alternative forms of conflict regulation, the rising number of non-state actors considered relevant to national definitions of security, and the expansion of the security agenda. (Sperling 2012, p. 33)

This flexibility, however, risks coming close to vagueness (see Sperling and Webber 2014). The academic literature on (or employing) the concept is frequently vague in its regard and altogether results scattered as far as empirical applications are concerned. On the contrary, however, there is a pressing need to consider what security governance adds to concepts conventionally used to register attempts at cooperation in the security field, and to evaluate the utility of this concept in a world that is getting all the more networked, regionalised, and complex with respect to the role of state and non-state actors. Given the nature of the challenges at play, the enhanced governance at the regional level, and the increasing relevance of emerging powers, regional security governance may prove to be an important field for theoretical investigation and empirical analysis.

In order to evaluate the usefulness of the concept of security governance and understand the current dynamics of regionalism, this work unpacks the concept and emphasises some of the shortcomings the literature has exhibited over the years. Hence, a first consideration on the peculiarities characterising the literature on security governance is provided in Section one. Section two goes deeper into the weaknesses characterising both the theoretical and the empirical research. Section three applies the framework to analysis of the Southern Caucasus region to see how security governance has played out there.

\section{A research agenda in need of improvements}

Beyond the fact that security governance refers to a complex set of challenges and coordination efforts at the global, regional, and local levels, there is no agreement on a specific definition or on the areas of application of the concept. All in all, by regrouping two already complex concepts, "security governance" has a lower clarity and theoretical intake than other concepts used in the traditional literature to refer to security cooperation (security regimes, security communities, concerts of powers, etc.). Moreover, the predominant attention to the "governance" (with respect to the "security") side of the label has further contributed to creating a sort of Babel-like literature where different authors look at completely different aspects of governance in the field of security. Should we have to list the most relevant characteristics of the current branch of the literature as a whole, we would point to the following:

First, a certain ontological heterogeneity. Different authors have focused on the different processes of decision-making and security policy implementation, which are characterised by fragmented power and authority within and outside the state (Krahmann 2003 , p. 6). We could perhaps say that the literature on security governance is divided in two main branches: one dealing with governmental actors (states and international organisations) (e.g. Kirchner and Dominguez 2011, Lucarelli et al. 2012) and one dealing with non-state and private actors (Bigo 2006, Leander 2006), with little interaction between the two and hence scant overview on how interaction leads (if at all) to a "multi-level governance" (Hooghe and Marks 2003).

Second, an epistemological heterogeneity. Part of the literature has a factual approach and looks exclusively at the network of relations among different actors; another branch 
pays attention to the intersubjective processes subsumed in the coordination attempts (Kirchner and Sperling 2007, p. 24). The importance of norms as distinctive traits of security arrangements is underlined by Sperling (2009), who highlights that the role that norms play in defining "state interests and acceptable behavior" is a stepping stone in regulation dynamics (p. 9).

Third, a predominantly empirical approach. As Sperling and Webber (2014) put it, "[s] ecurity governance entails an implicit and sometimes explicit importation of theoretical premises (e.g. on institutions and norms) but makes no significant stand-alone theoretical claims" (p. 129; see also Christou et al. 2010). In fact, most of the existing literature on security governance has featured empirical case studies. Significant exceptions are the conceptually dense work of Kirchner and Sperling (2007) on security governance in Europe, and that of Sperling (2014) extending the theoretical breadth of the concept and its areas of application.

Fourth, for a long time, the literature on security governance has been characterised by a predominantly narrow European focus. In particular, either this literature has focused on the contribution of the European Union (EU) to the global governance of security or it has referred to the EU as typifying a security governance system. ${ }^{1}$ This is not surprising given the EU's institutional model. It is also not surprising given the increasing amount of scholarship on the EU's contribution to holistic security (from the fight against climate change to peacekeeping). However, the predominant attention to EU dynamics might have biased global security governance theorisations and analyses, or overlooked systems of security governance developed and implemented in other regional contexts.

As we have seen, the literature on security governance is now broad and growing, but with some gaps and shortcomings. We believe that this branch of the literature would gain from an attempt to overcome four of these. First, greater attention should be paid to the subjective and intersubjective dimensions of security, by investigating how security is understood and perceived by the actors involved in the governance system. Second, it would be useful to explore the relationship between the cognitive definitions of a region and security dynamics much more in depth than has been done thus far. Indeed, a region can be defined precisely because of processes of securitisation at the regional level. Third, attempts should be made to make sense of the coordination efforts (or the lack thereof) among different actors and layers of governance. In other words, the context of interaction is key to understanding security governance, even when focusing attention predominantly on states (regional state powers). Finally, an effort should be made to look at extra-European dynamics, also with the aim of evaluating the relationship between political/security culture and security governance, as well as between political/economic development and security governance.

The following section clarifies these points.

\section{Making the concept relevant}

\section{Bringing back security and its intersubjective dimension}

As argued elsewhere (Christou et al. 2010, Ceccorulli and Lucarelli 2012, 2014), in the existent literature more attention has been devoted to "governance" than to "security", while 
greater attention should be paid to how security is understood and perceived by the actors involved in the governance system.

The scarce attention devoted to security and its shared (or not shared) understanding among different actors is widely acknowledged in recent academic contributions, which instead put security, its understandings, and implications at the centre of their reflections (Buzan and Hansen 2009, Floyd and Croft 2010). The security governance literature would benefit from a dialogue with these works, for instance, by paying more attention to "securitisation" and "de-securitisation" dynamics, which affect both the very definition of a problem as a security challenge and the modes of security regulation. Variants of these approaches insist more on discourses or practices as relevant determinants in securitisation processes (Bigo 2000, Wæver 2004). In such a way, it is possible to discover both how traditional and particularly how new issues arise as security concerns requiring cooperation, providing a benefit to security governance compared to other traditional concepts.

In other words, the research agenda would draw advantage from a deeper reconsideration of what security is today: of the actors (see below), referents (suffice it to recall the concepts of societal or human security), issues (energy, migration, climate change, food, organised crime, and cyber activities), and practices of collective attempts (multilevel, formal/informal, and ad hoc/institutionalised) aimed at tackling ongoing challenges. Also, it would also be beneficial to consider the extent to which security understandings are shared among different actors, and what this determines in terms of collective security efforts (Ceccorulli and Lucarelli 2012, 2014).

\section{Bringing in the social construction of regions}

The literature on security governance has only recently started to deal with regional security dynamics, either by comparing different regional security organisations (Breslin and Croft 2012, Kirchner and Dominguez 2011, Sperling 2014 chapters 25-37), or by exploring the specific security dynamics in one geographic region (Acharya 2012, Adler and Greeve 2009, Sperling 2014 chapters 7-14, Kacowicz and Galia Press-Barnathan 2016). As a matter of fact, we have been witnessing a regionalisation of security which is interestingly intertwined with the globalisation of security challenges. Global security challenges (financial crises, climate change, and transnational terrorism) have a very different regional impact and give rise to different threat assessments and responses in different regions. Despite this renewed attention to regional security dynamics, however, some improvements could also be made as far as scholarship in this endeavour is concerned. In particular, we propose widening the dialogue with the International Relations (IR) literature on security regions and using social constructivism as far as the meaning of regions is concerned. Let us touch on this.

The IR literature has produced various contributions to understanding the relationship between security and regionness (see Lucarelli et al. 2013, Fawn 2009, Paasi 2009), among which are "security communities" (Deutsch et al. 1957, Adler and Barnett 1998) and "regional security complexes" (Buzan and Weaver 2003). A security community is defined by a shared understanding of security among the units (states) in the area, which, as a result of shared identities, values, and diffuse reciprocity, stop feeling threatened one by the other. On the contrary, a regional security complex is a set of states 
whose major security perceptions and concerns are so interdependent that their national security problems cannot be tackled individually (in this case, no substantial change of identity is foreseen). In both cases, the security region is a social construction: ${ }^{2}$ a geographic region might be neither a security community, nor a regional security complex. Moreover, each of these types of security regions is characterised by different security governance that could be explored through the lenses of the security governance literature (Adler and Greeve 2009). In a security community, the degree of institutionalisation is quite high, and the role of non-state actors is all the more relevant as the region moves from a "pluralistic" to an "amalgamated" form (to use Deutsch's categories referring to a growing level of supranational governance). On the contrary, patterns of amity and enmity may vary among regional security complexes; hence, the interaction context may well lead to different governance modalities. In other words, regional security complexes are security regions sometimes with little shared governance. An analysis of regions defined by security concerns in order to explore their nature and governance implications could be an added value for the concept of security governance.

Research on the role of state actors in regional security governance would also have to look at the states' interpretation of what their region of reference is, as well as how their interpretation of security threats contributes to shaping a cognitive region in the area that could be the basis for a regional system of security governance. Hence, cognitive, power, and geographic determinants are to be taken into account as shapers of regional framings, while none of them is excluded a priori through the usage of a term such as security governance.

\section{Bringing in state and non-state actors}

That the security landscape is characterised by a growing range of different actors is widely recognised (Krahmann 2005, 2010, Bryden and Caparini 2006, Westermeyer 2013, Abrahamsen and Leander 2015), either as an agent of security threats (e.g. terrorists and organised crime networks), referents (society and human beings), or as parts of the security management process.

And yet, one has to recognise that, for obvious and valid reasons, works on international organisations (IOs) engaged in security at various levels, and on states, are still predominant in the security governance literature. The new IOs' playing field mostly seems to be the regional level. One promising (and less explored) strategy of enquiry so as to jointly consider a broad array of different actors in the governance process is to focus on the states that are emerging as crucial actors in their region's security governance, and to explore their relationship with other actors such as (regional and global) IOs, other states, and non-state/private actors. The reason is clear: states continue to retain a great amount of not only material, but also ideational power in world politics. From a material viewpoint, they can either support the IOs' work or not, allocate resources, and make specific decisions. From an ideational viewpoint, they have a subjective perception of security dynamics which interacts with those of the other actors in the system and contributes to shaping the shared (or not shared) perception of a security threat and apt response. Not only that, the relevant states in a region (or globally) are engaged in a process of intersubjective redefinition of the shape of the (regional) governance and of the interpretation of existent norms. 
Therefore, focusing attention on these actors, exploring their material and ideational preferences, and their interactions with other state and non-state actors is a promising line of research that can contribute to understanding the wider transformation of security governance.

\section{De-Europeanising}

The literature has predominantly focused on the EU/Europe and the transatlantic area. Some interesting contributions on non-European regions have appeared more recently (e.g. Acharya 2009, 2012, Adler and Greeve 2009, Börzel and Risse 2016), and Sperling's (2014) insightful Handbook of governance and security hosts contributions on security governance in several parts of Asia, South America, the Persian Gulf, and the Arctic region; however, all in all, the approach continues to be predominantly focused on Europe/the EU. As a matter of fact, a large part of the literature explicitly uses the term security governance to either refer to the EU as exemplifying a distinct way of arranging relations in a context with post-Westphalian traits, or to make sense of coordination attempts within the EU (Kirchner and Sperling 2007, Bossong 2008, Lucarelli et al. 2012). However, the EU might even not make "post-Westphalian" moves in its external action and, at the same time, more Westphalian entities can be pushed to security governance by the challenges ahead. Indeed, agreement on what constitutes a challenge and at least compatibility between security perceptions are the sine qua non for coordinated actions. This is not to say that similarly perceived collective problems are easily dealt with; on the contrary, even a similar perception of security may not be enough for coordination due, among others, to power considerations, different strategic cultures, and other causes. While quoting Schroeder, Sperling and Webber underline not only that security governance may be inefficient, but also that harmonious interaction is not a necessary feature of governance structures (Sperling and Webber 2014, p. 129).

The empirical literature should thus focus more robustly on how security is perceived in different contexts, whether shared understandings exist, and what they give rise to in terms of security dynamics. This path has already been followed, particularly as far as Asia is concerned (e.g. Acharya and Buzan 2010, Gwi-Ok 2013, Sperling 2014, chapters $8,13,14$, Börzel and Risse 2016), but it could be followed more systematically for other regions of the world.

So, how to proceed from here? One of the proposed aims of this work, that is, to deEuropeanise the literature on security governance, is pursued through the analysis of security governance in the Southern Caucasus; in other words, the geographical area encompassing Georgia, Armenia, and Azerbaijan. Often described as fraught with traditional security threats and classic intergovernmental dynamics, this geographical area may seem unsuited to the application of security governance as a concept. Instead, the Southern Caucasus is a very good example of a region largely constructed through and around security concerns, either among the members of the regions, or between one/ all of them and a specific external actor, as a result of security practices by external actors. Moreover, security perceptions include new security challenges. Finally, in some issue areas considered key for the security of all the actors involved in the interaction context - such as energy in this case - private actors may exert a significant role. Ultimately, policy complexity and the presence of "legitimate and purposeful" actors asking 
or helping to produce security (Sperling and Webber 2014, p. 133) allow the concept to be applied in the context under analysis.

\section{Constructing the region: the role of protracted conflicts, external actors, and energy in the Southern Caucasus}

There is an open debate on the possibility of considering the Southern Caucasus as a region in its own right. While it is true that there are some identifiable geographic "constraints", they do not clearly delimit the region. Three of the four sides surrounding the Southern Caucasus are somehow influenced by geography. The Black Sea coast to the west, the Caspian Coast to the east, and the Greater Caucasus chain to the north stand as the "natural" limits of the region. Moreover, the imperviousness of the Caucasian heights and the scarcity of crossing points between the two sides have led to distinct development processes in the northern and southern parts of the chain. On the contrary, the fourth border, to the south-west with Iran and Turkey, respectively, has been fixed by diplomacy rather than geography, after centuries of successive modifications (the RussoPersian treaties of Gulistan (1813) and Turkmenchay (1828), and the Treaty of Kars (1921)). Not by chance, the fluidity of the southern and eastern borders has encouraged migration flows and facilitated cultural exchanges and penetration from the Turkic and Persian worlds - whose influence is a key cultural marker of difference between the southern and the northern parts of the Caucasus.

The Southern Caucasus has also not behaved as a region in institutional terms. It is precisely for this reason that recently a wide consensus has emerged around the concept of "broken region", exploited by both scholars and practitioners (Semneby 2006, DeWaal 2012, Boonstra and Delcour 2015). Precisely because the Southern Caucasus is a hard case, in the following paragraphs we show that there are elements for analysing it through the concept of regional security governance due to the mutually constitutive effects of "security concerns" and "regionness".

Four main elements have contributed more than others to the definition of the Southern Caucasus as a region in security terms: unsolved regional conflicts, the role of external and non-state actors, and energy dynamics. In other words, the securitisation of both traditional security issues such as protracted conflicts, and a new security issue such as energy has been a fundamental element in the definition of the Southern Caucasus as a region and for the analysis of the ensuing security governance. At the same time, it would not be possible to understand Southern Caucasus security dynamics without looking at the role of third actors.

\section{The role of protracted conflicts}

In the case of the Southern Caucasus, what has mostly defined the region in the post-Cold War period is the same element which has made security governance extremely complicated: namely, the persistence of unresolved ethnopolitical conflicts in Abkhazia, South Ossetia, and Nagorno-Karabakh. These conflicts have stood as the key obstacle to enhancing regional stability as well as to developing inclusive regional coordination efforts; and all the more so since the conflict over Nagorno-Karabakh has put two of the three regional actors, namely Armenia and Azerbaijan, in contrast since 1988. Yet, by shaping the three 
states' perceptions of threats, the protracted ethnopolitical conflicts have also worked as the main elements around which a regional security complex has developed.

As a matter of fact, it is mainly around these conflicts that analogous yet diverging security perceptions and policies have come into being; it is around these conflicts that analogous yet opposed alignments with third actors have been pursued by the local actors; and, finally, it is also around them that similar national security narratives have been proposed. A clear example of the latter is the shared narrative of what can be called "mutilated sovereignty". Following the dissolution of the Soviet Union, the socalled Newly Independent States had to jointly tackle difficult state- and nation-building processes, which in many respects overlapped and merged with the construction of nation states. From this perspective, the "mutilated sovereignty syndrome" pointed to the fact that not only would the state-building process be incomplete without the contested territories, but also that the nation-building process would inevitably be incomplete, identity would be "mutilated", and therefore "ontological security" not achieved. ${ }^{3}$

Such a narrative has become part of the self-representation of the three states, regardless of whether their aim is to acquire new territories - as with Armenia ${ }^{4}$ - or, rather, to assert the inviolability of those inherited from the dissolution of the Soviet Union - as with Georgia and Azerbaijan which, de facto, have lost control and sovereignty over a large portion of their respective national territories. Such a shared sense of incomplete ontological security emerges clearly from the Southern Caucasus Republics' (SCRs') national security documents (NSDs), ${ }^{5}$ where a process of "securitisation of national identities" is clearly detectable. For instance, the link between the aims of safeguarding both national identity and territorial reintegration is made explicit through the accusation - set out in the Azerbaijani and Georgian NSDs - of cultural attacks and annihilation implemented by the occupying forces in the contested territories (AzNSD - National Security Concept of the Republic of Azerbaijan 2007, p. 4, GeNSD - National Security Concept of Georgia 2011, pp. 10, 27).

Of added relevance, the presence of protracted conflicts has produced an inevitable impact on the SCRs' threat assessment and security priorities, as is clear from the analysis of the respective NSDs. Both Georgia and Azerbaijan elevate acts against sovereignty and territorial integrity of the state to main security threats, explicitly referring to the "military occupation of part of the Georgian territory by the Russian Federation" and to the "aggression of Armenia", respectively (GeNSD - National Security Concept of Georgia 2011, p. 7, AzNSD - National Security Concept of the Republic of Azerbaijan 2007, p. 3). Symmetrically, the settlement of the Nagorno-Karabakh conflict is referred to in the Armenian NSD as a "key issue of the National Security of the Republic", along with the aggressive stance of the Azerbaijani government and potential military operations against Armenia and/or Nagorno-Karabakh (ArNSD - National Security Strategy of the Republic of Armenia 2007, p. 3). The key role of protracted conflicts in shaping the SCRs' threat environment also emerges from the perceptions of civil society, as reported in several surveys carried out at the national level. ${ }^{6}$

Besides determining a shared perception of a "mutilated sovereignty" and a joint priority over traditional security concerns such as sovereignty and territorial integrity, the protracted conflicts have generated an elevated degree of security interdependence among the SCRs, even beyond the traditional arms race which Armenia and Azerbaijan have been caught up in, especially in the last decade. It may be said that the "no-war no-peace" condition affecting the Southern Caucasus and the resulting mutilated sovereignty syndrome have given rise to the interconnectedness of security, the need for interstate cooperation, 
and, finally, relations with non-state subnational actors. Falling among the latter are not only the secessionist entities lacking sovereignty de jure but de facto behaving like state actors, but also those subnational actors which, although unsuccessful in the establishment of proto-state structures, nevertheless in different ways and with different intensities challenge the patron state's sovereign prerogatives - for example, the Ajaria and Javakheti regions in Georgia or the Talysh and Lezghin groups in Azerbaijan. The security interdependence resulting from the protracted conflicts mainly takes two forms. First of all, by fostering instability and weakening state control over the national territory, conflicts are perceived by the SCRs as impinging upon human security, not only by causing humanitarian emergencies, but also by providing a "fertile ground for trans-national organised crime and other illegal activities" (ArNSD - National Security Strategy of the Republic of Armenia 2007, p. 5, GeNSD - National Security Concept of Georgia 2011, p. 9). Second, and most importantly, conflicts have contributed to the securitisation of the sustainability of the domestic economy, which has gradually emerged as a new cornerstone in the SCRs' national interest. As a reaction to the risk of state failure which affected the SCRs in the aftermath of the Soviet dissolution, the regional actors came to see economic stability and a sustainable path of development as key pillars of their own security strategies, as set forth in the respective NSDs. The Azerbaijani NSD lists both economic dependence and economic destabilisation as key security threats to the country (AzNSD - National Security Concept of the Republic of Azerbaijan 2007, p. 6), as do Armenia and Georgia (ArNSD - National Security Strategy of the Republic of Armenia 2007, p. 5, GeNSD National Security Concept of Georgia 2011, p. 3). The linkage between regional security interdependence and the securitisation of economic development is all the more relevant due to the land-locked nature of two out of three SCRs, which implies by definition the need for dialogue and cooperation with the neighbouring transit state(s).

What is worth noting is that, mainly due to the protracted conflicts, external actors contribute to the definition of the region in security terms. By extending the Eastern Partnership (EaP) to the three Southern Caucasus countries, the EU has emphasised the relevance for European security of stability in this region. ${ }^{7}$ As far as Russia is concerned, since the beginning of the 1990s, one of the main drivers projecting towards the Southern Caucasus has been the need to avoid the spillover effects of regional conflicts through the Federation's border (Ministry of Foreign Affairs of the Russia Federation 2013). Finally, the failure of the 2009 Turkish-Armenian normalisation process as a result of the impossibility for Ankara of decoupling the bilateral negotiation with Yerevan from the Armenian-Azerbaijani negotiations over the Karabakh conflict - still responsible for the 1993 closure of the border between Turkey and Armenia - perfectly embodies the regional dimension of Turkey's security perceptions and behavioural patterns.

To sum up, the analysis of the SCRs' NSDs seems to demonstrate that protracted conflicts can be considered as region-building factors in the Southern Caucasus in that they impact on the countries' self-representation, their threat assessment, and the external perception of the ensemble of the SCRs as a region.

\section{Third actors and regional dynamics}

As we have already shown, in terms of external governmental actors, the main role in the Southern Caucasus is played by neighbouring countries (Russia in the first place) and 
international organisations such as the EU and the North Atlantic Treaty Organization (NATO). Since the dissolution of the Soviet Union, regional policy has revolved around the attitude of the SCRs towards Russia. This has resulted in very different outcomes, and in particular in the tendency to forge identity-based foreign policies. This tendency has seen the three SCRs walk very different and sometimes clashing paths in regional and international politics. For Georgia, the rejection of its Russian and Soviet past led to a marked pro-Western identity orientation. In the case of Armenia, besides the traditional cultural linkages which tied the New Independent States to Russia, the close relationship between Erevan and Moscow was fostered by the perceived return of the existential "Turkic threat", coming jointly from Turkey and Azerbaijan.

Iran and Turkey also play a relevant role in self-representation and strategic choices. For example, while it is essentially Russia and Iran that provide the key political and economic channels of communication to Armenia, the same role is played primarily by Turkey in the case of Azerbaijan through the rediscovery of ethno-linguistic ties between the two countries. The centrality of these actors is widely recognised in official documents, given the land-locked nature of these SCRs (ArNSD - National Security Strategy of the Republic of Armenia 2007, pp. 15-16, AzNSD - National Security Concept of the Republic of Azerbaijan 2007, pp. 12-13). Therefore, the interactions between the SCRs and their external neighbouring actors have created a fragmented yet interdependent governance system, by fostering the creation of two analogous and opposed axes for cooperation spanning along east-west and north-south lines, respectively involving Azerbaijan, Georgia, and Turkey on the one hand, and Russia, Armenia, and Iran on the other hand.

The role of external neighbouring actors - that is, Russia, Turkey, and Iran - is further enhanced by the presence in the Southern Caucasus of different ethnopolitical tensions which, despite not exploding into armed conflicts, have nevertheless returned several times to threaten the security and stability of the SCRs and to generate interstate frictions. In fact, ethnic minorities akin to the ethnic groups dominant in neighbouring states or regions are present in all the SCRs. In some cases, ethnopolitical issues and sometimes religious ones feed outstanding cross-border issues, generating more or less hidden bilateral tensions. The most obvious case is that of Georgia not only with the Abkhazia and South Ossetia state-building process, but also with the Muslim minority in the Autonomous Republic of Adjara, strengthened by close ties with Turkey. Similar tensions regard Azerbaijan and its two ethno-linguistic minorities - Lezgin and Talysh - which have strong ties with Russia and Iran. In turn, much of Azeri ethnicity is located beyond the southern border with Iran where between 15 and 20 million Azeris reside. These realities add to the presence of Armenian and Azerbaijani minorities in Georgia and Georgians in Azerbaijan (but not Armenian minorities in Azerbaijan and vice versa), contributing to a wide and interconnected web of transnational relations not free from security connotations. Indeed, the risks associated with centrifugal forces tend to span across borders and often to be supported from outside the borders.

This identity-based determinant of the state- and nation-building process has been closely linked to the definition of security perceptions and can be further gleaned by looking at the orientation towards different external security organisations in the region, all of which overstep the geographical borders of the region. Even though Armenia is the only state having a collective security agreement with an external country (Russia, through the Collective Security Treaty Organisation), all of them are 
somehow engaged in relations with security organisations. The three countries are part of the EU's EaP programme, which focuses especially on "new" security challenges. At the same time, the three countries are part of NATO's Partnership for Peace (PfP) programme. Indeed, the inauguration of dialogues with Western organisations, mainly NATO and the $\mathrm{EU}$, has contributed, at least in the rhetoric, to putting the priority on new security issues. In 2003, NATO, for instance, launched the South Caucasus Cooperative River Monitoring Project under the aegis of NATO's Science for Peace and in cooperation with the Organisation for Security and Co-operation in Europe. The project aimed to establish a social and technical infrastructure that could monitor the water quality and quantity of trans-boundary rivers and ease data-sharing between the SCRs, to avoid water disputes that have the potential to intensify political and ethnic instability (NATO 2005).

Released for the first time between 2005 and 2007, the three NSDs reflect and are influenced by the visions and expectations of the Euro-Atlantic partner which fostered the drafting of the documents. This resulted in a very wide conception of national security, which is not merely state-centric but looks at individuals and citizens as beneficiaries of state policies; which does not only consider conventional threats, but is also open to non-traditional ones; which, not least, considers human security - in its economic, cultural, and environmental dimensions - as relevant as military security. Moreover, besides influencing the SCRs' security conception and discourse, external actors have given a steady contribution to relating to the Southern Caucasus as a coherent region, as already shown in the case of protracted conflicts and energy, therefore fostering an integrated approach. For instance, besides working at a bilateral level within the PfP or the Individual Partnership Action Plan (IPAP) frameworks, since the end of the 1990s, NATO has developed a regional approach towards the area. This trend materialised for the first time through the creation of an open-ended ad hoc working group on the Southern Caucasus within the Euro-Atlantic Partnership Council dealing with defence, economic issues, civil emergency planning, science and environmental cooperation, information, and public relations. This trend culminated on the eve of the 2004 enlargement in the decision, adopted at the Istanbul 2004 NATO Summit, to provide the alliance with a special representative to the Caucasus and with a liaison officer. Following the same logic and almost the same timeframe as NATO, the EU developed a regional approach towards the Southern Caucasus first by appointing a special representative to the area in 2003, and successively by extending the European Neighbourhood Policy to the region in 2004 and, finally, through the launch of the EaP in 2009.

All in all, though, in terms of security governance, this variegated geometry has resulted more in bilateral initiatives than in multilateral attempts at solving potential threats, a trend to which Western organisations have somehow contributed. An exception to this is the Minsk Group for mediation in the Nagorno-Karabakh conflict. Under the auspices of the Organization for Security and Cooperation in Europe (OSCE), the group (cochaired by France, the USA, and Russia) aims to encourage the negotiation process between Azerbaijan and Armenia, increase the chances of a permanent ceasefire, and promote the peace process through OSCE peacekeeping forces.

Finally, there is another aspect of the role of third actors that should be mentioned here: the increasing relevance of international organisations in the governance of especially new security issues. For instance, UN agencies in cooperation with OSCE target regional environmental security in the Southern Caucasus through the Environment and Security 
Initiative (ENVSEC), dealing with environmental degradation and access to natural resources in areas of conflict; management of trans-boundary natural resources; rapid population growth; and strengthening the role of civil society in environmental decision-making. Analogously, in the area the International Center for Migration Policy Development and the United Nations High Commissioner for Refugees deal with the issue of refugees and internationally displaced persons, which in all states is interpreted as a key obstacle to the solution of long-standing tensions in the region.

\section{Energy}

The Southern Caucasus provides a privileged testing ground to highlight how energy contributes to the security definition of the region and its governance patterns. As such, a key event was the opening of the first oil and gas pipelines linking Azerbaijan to the regional and international markets through the territories of Georgia and Turkey - that is, the BakuTbilisi-Ceyhan (BTC) and the Baku-Tbilisi-Erzurum (BTE) pipelines. The Georgian NSD explicitly refers to the mentioned infrastructures, highlighting that they "not only are economically important, but they also increase stability in the region". Likewise, the realisation of new projects "involving the resources of Azerbaijan and Central Asia and making full use of the Georgia-Azerbaijan transit corridor - will strengthen regional security. This is in the interests of Georgia and Azerbaijan, as well as of other states" (GeNSD - National Security Concept of Georgia 2011, p. 18).

Indeed, energy concerns have been differently securitised within the region. For Azerbaijan and Georgia (energy exporting and transit countries), hydrocarbon exports have been securitised in that the stability of flows means ensuring economic security. The exploitation of the "oil and gas" sector is not just a matter of economic development, notwithstanding the significant financial return for the state budget, directly and in terms of the influx of foreign direct investments. Ever since the start of the Caspian "black gold rush" in the 1990s, the possibility to become an energy security provider to international actors came to be viewed as a key, yet indirect guarantee for state security and sovereignty, an "insurance policy" for national independence (Pashayev 2009, p. 114). In terms of hydrocarbon reserves, Azerbaijan is indeed the Southern Caucasus' powerhouse. This advantage is strongly reduced because of the land-locked nature of the country, compelling Baku to cooperate with transit states - and, particularly, with Georgia - in order to translate its extraction potential into economic advantages. While the relevance of Georgia to Baku's energy and security policies is recognised in the NSD itself (AzNSD - National Security Concept of the Republic of Azerbaijan 2007, p. 13), Azerbaijani dependence on Georgia as a transit state is, in turn, mitigated by the hybrid nature of the latter, as simultaneously a transit country and consumer of Azerbaijani hydrocarbons. Such a relationship clearly creates similar concerns over the stability of the hydrocarbon flow and possible disruptions caused by regional infightings. ${ }^{8}$

Not less relevant is Georgia's contribution to the framing of energy as a security issue. In this case, the securitisation of energy occurs by acknowledging itself the role of "regional security provider" as a transit country (GeNSD - National Security Concept of Georgia 2011, p. 24). For Armenia, which does not possess indigenous resources, it is energy dependence to be securitised given the closure of its eastern and western borders as a result of the Nagorno-Karabakh conflict, as well as the Azerbaijani policy isolating Armenia from 
regional infrastructural projects (Aliyev 2012). This has drastically reduced the possibilities for the development of diversified energy links and left Armenia vulnerable to a double dependency: on Russian energy supplies and Georgian transit routes. Moreover, the country's dependence on Georgian transit routes goes well beyond the energy sector, to the point of considering the dependence on the neighbouring country's infrastructures and the isolation from regional transport projects as a central source of vulnerability (ArNSD - National Security Strategy of the Republic of Armenia 2007, p. 4). Therefore, the possibility of "ethnic conflicts, internal unrest and military activities in neighboring states" impinging upon the stability of the energy supply is considered a key external threat (see ArNSD - National Security Strategy of the Republic of Armenia 2007, p. 5) - the more so in relation to the key role attributed to energy in supporting the development, growth, and independence of the country.

Energy sector governance in the Southern Caucasus contributes to defining a central feature of the regional security governance, namely, a certain flexibility in membership according to security categories (of inclusion and exclusion). In other words, the region's security governance moves from a shared understanding of security as well as from shared security perceptions (cognitive element), but heads towards analogous yet opposed practices, primarily due to the regional polarisation resulting from unsolved conflicts.

It is worth noting here that the political and strategic understanding of the energy sector's development was also paramount for Western consumer states, which indirectly contributed to the fragmentation of the governance system. Besides the advantages in terms of international competition in energy markets, the exploitation of regional resources was seen as a key tool for supporting post-Soviet state-building processes, ensuring stability to a high volatile region shaped by the risk of state failure, and, finally, strengthening state sovereignty before the risk of falling into the sphere of influence of rogue regional powers - namely, Russia and Iran. Over the 1990s, it was primarily US initiative that provided local producers with extra-regional financial and political support with a view to initiating an energy corridor from Central Asia to Turkey through the Southern Caucasus (Gilman 1997, pp. E2240-2; see also the White House 1997, p. 72). Once again, the role of external actors contributed to making energy a regionbuilder in security terms. Indeed, once the first exploration and production contracts for the Caspian fields were signed, the relation between energy and security became closer and, simultaneously, the infrastructural development should have provided a key incentive for transnational cooperation among the regional actors involved. This was, for instance, the main driver behind the establishment of the GUAM organisation (1997), bringing together Georgia, Ukraine, Azerbaijan, and Moldova, united, among other things, by the will to jointly develop energy infrastructure projects.

The role of incentive for regional and interregional cooperation played by the energy sector along fragmented yet interdependent lines re-emerged after the inauguration of the BTC and South Caucasus Pipelines (SCP). The laying of the oil and gas pipelines cemented the producer and transit states' mutual interest towards a stable flow of hydrocarbon, thus offering Azerbaijan, Georgia, and Turkey a fresh stimulus to strengthen existing bilateral and newly created trilateral channels for dialogue and cooperation (AzNSD - National Security Concept of the Republic of Azerbaijan 2007, GeNSD - National Security Concept of Georgia 2011). The shared interest in keeping uninterrupted exchanges extended to the 
broader aim of preserving good neighbourhood relations and subregional stability (Republic of Turkey 2012). What is worth noting with regard to the above-mentioned cooperation experiences is that both of them were explicitly linked to the regional policies of external actors - namely, the USA as per the GUAM and the EU as per the AzerbaijanGeorgia-Turkey project. Conceived within the framework of the EU's "external" energy policy, the latter revolved around the need to protect European energy security through the diversification of supply channels. As such, ever since the publication of the European Commission's dedicated 2000 Green Paper (European Commission 2001), the Southern Caucasus area and the Caspian Basin became a priority vector for the policies aimed at safeguarding EU energy security from outside its borders.

The energy sector also proves to be relevant to the case study in that it allows the limited yet significant contribution provided by private, non-state actors to security governance to be highlighted, that is, the role played by international oil companies (IOCs) in the governance of an issue jointly perceived as a security challenge, as seen above. Mediating between the local and external state actors' interests and policies, IOCs bear corporate interests which represent a key vector to advance the national interest of both the consumer and the producing states; as such, though, they may not be merely considered business actors. Moreover, in many cases - and specifically in the case in point - IOCs conduct their business by relating to the national oil companies owned by producing states, which show the clear tendency to handle them as a key foreign policy tool. Last but not least, increased interaction between the public and private sectors helped depoliticise an issue, namely, the management of pipeline security, which in the past marked a dangerous friction point in the region, as a result of the attempt to directly involve NATO.

As a consequence of the initiation of energy exports from Azerbaijan through the Southern Caucasus, the interests and policies of Baku and Tbilisi, on the one hand, and of the IOCs, on the other, welded around the aim of ensuring the stability of the energy flows as well as the protection of infrastructures. The increased interaction between the public and private sectors is chiefly the result of the regional initiatives of British Petroleum (BP) - the single largest foreign investor in Azerbaijan and key shareholder in the BTC and BTE pipelines. Acting on the basis of the "Voluntary Principles on Security and Human Rights", which provide extractive industry companies with a framework to maintain the security of their operations while ensuring respect for human rights, BP has implemented significant security measures along the energy routes, mainly in the form of patrolling and monitoring. Simultaneously in Georgia, by virtue of a bilateral security agreement signed with the government, BP is training and funding the Strategic Pipeline Protection Department, an ad hoc task force designed for infrastructure security. In Azerbaijan, BP has implemented facility protection and security guard services through its private security provider, Titan D, while closely cooperating with the Export Pipeline Protection Department, the government agency appointed for infrastructure security.

Alas, the role played by private actors is not replicated in other issue areas. However, the IOCs' contribution to the provision of security in the energy domain is effective and significant. As such, they are part of the interaction context characterising regional security governance and provide cues as to the overall system of security governance in the Southern Caucasus: quite Westphalian as regards the centralisation of power, but inevitably open to inference by private actors in the handling of a key "regional" security concern. 


\section{Conclusions}

Security governance is a useful concept for capturing the complexity of the management of security in the current articulated international and regional scenario. The same concept, however, risks being too loose to be a useful guide to research if scholars do not deal with some of the shortcomings encountered so far.

To make the concept more useful for an assessment of current security dynamics, four main shortcomings need to be overcome: in the first place, greater attention should be paid to how security is understood and perceived by the actors involved in the governance system. In particular, in this article, we have explored the perceptions of three state actors of such a system: Armenia, Georgia, and Azerbaijan.

Second, it would be useful to explore the relationship between the cognitive definitions of regional and security dynamics. In this article, we have shown the relevance perceptions for the understanding of the Southern Caucasus as a region, which play a major role together with security dynamics than geographic morphology.

Third, the literature should look at both governmental and non-governmental actors and their interaction. In this article, we have made an attempt to integrate the analysis of the main actors in the governance system (the region states) with the analysis of the role of non-state actors. However, admittedly, while the role of IOs could prove to be relevant, that of private non-state actors has only been explored with respect to energy security. In this case, the role of these actors and their interaction with governmental actors prove to be tangible and relevant; however, more research would need to be done to integrate their role better in the analysis of regional security governance.

Finally, this article is an effort to look more deeply at extra-European security dynamics, by looking at the Southern Caucasus.

More precisely, what have we learned on regional security governance in the Southern Caucasus? By exploring the Southern Caucasus in terms of security perceptions, regionbuilding practices, and roles of different actors (region states*, external powers, international organisations, and some private actors), the analysis has shown that the area has gradually come to be identified as a region due to processes of securitisation, and to the role of external actors and their interaction with regional security dynamics. First, the overarching presence of a set of security concerns related to the so-called protracted conflicts has impacted on the main states' self-identification and security priorities, as well as on external actors' identification of the Southern Caucasus as a security region. Second, these external actors seem to have directly and indirectly interfered with regional security dynamics. The net effect has been both disaggregative and aggregative, while contributing to make the boundaries of the region blurred and attaching "regionness" qualities to the dynamics happening in the area. Third, the securitisation of energy has been shown as contributing to the regionalisation of the area in security terms, by creating security interdependencies among the states independently from their nature as producers or consumers of energy. Even though the role of private actors is not overwhelming in the region, they do exist and perform key tasks for energy security in the region.

The resulting image is one that comes close to what the literature calls a "security complex" with a high integration of security concerns and priorities (also in ontological security terms), and a diffused form of security governance, with a variable, mostly bilateral geometry, involving predominantly governmental and to a small extent non-governmental actors. 
What does this case tell us about the concept of regional security governance?

In the first place, it shows that a system of regional security governance can be widely shaped by cognitive processes, whereby the security of different actors in a region comes to be perceived as interconnected, and that the "objective" entity of such an interconnection is far less relevant than the perception of it. Ultimately, it is the very existence of a perception of being interdependent from a security point of view which gradually defines the region; the region is primarily a security region.

In the second place, state-, nation-, and region-building dynamics can be all influenced by securitisation processes: eventually, a region results from dynamics of ontological security rather than from a cooperative attempt at constructing a regional security governance.

Third, the case shows that a security region can also be formed around non-traditional security concerns that are securitised (such as energy in the case of the Southern Caucasus).

Fourth, the actors involved in the regionalisation-through-securitisation process are by no means only the relevant regional states, but also external state and non-state actors, while private actors only marginally (though significantly) take part.

Fifth, "governance" in a regional security governance system does not need collective management. In fact, in the case of the Southern Caucasus, there is no collective or inclusive management of security, but a variable geometry of governance which includes different actors at a time.

The construction of security regions through different securitisation processes, actors, and dynamics is what we think could add purchase to regional security governance as a concept as well as providing an analytical tool for analysis.

\section{Notes}

1. The literature on EU security governance is now rather wide-ranging; alongside the works already cited, there are contributions by Christou et al. (2010), Daase and Friesendorf (2010), Hallenberg et al. (2009), Kaunert and Léonard (2013), Lucarelli et al. (2012), Sperling and Webber (2014), and Sperling (2014).

2. A good approach to this in Hemmer and Katzenstein (2002) and Adler (1997).

3. To be ontologically secure a state must possess answers to fundamental and existential questions (Steele 2008), and state borders of sovereignty and citizenship are fundamental questions. The lack of ontological security impedes the reassuring routinization of actions that is so important to stets' identity (Steele 2008).

4. It is worth noting that the annexation of the Nagorno-Karabakh does not represent the official Armenian policy line towards the conflict, nor has Erevan granted official recognition to the selfproclaimed Republic of Nagorno-Karabakh. However, Armenia grants support to the separatists and in its national security strategy it reaffirms its role as "the guarantor of the safety and security of the population of the Republic of Nagorno Karabakh (Artsakh)" (2007, p. 9).

5. The main security documents of the Southern Caucasus countries are, respectively, the ArNSD National Security Strategy of the Republic of Armenia (2007), the ArNSD - National Security Concept of the Republic of Azerbaijan (2007), and the GeNSD - National Security Concept of Georgia (2011). For simplicity, in this article we regroup them as "national security documents", while we refer to them separately as AzNSD (for Azerbaijan), ArNSD (for Armenia), and GeNSD (for Georgia).

6. See, for instance, the Caucasus Research Resource Center's "Caucasus Barometer" data set at http://www.caucasusbarometer.org.

7. A similar process has occurred as a by-product of the EU's needs to securitise energy. 
8. The Azerbaijani NSD highlights that "[r]evenues generated from the development and transportation of the energy resources constitute a valuable asset for the economy [...] Therefore, attempts to undermine this sector [ ... ] are among potential threats" (AzNSD - National Security Concept of the Republic of Azerbaijan 2007, p. 6).

\section{Disclosure statement}

No potential conflict of interest was reported by the authors.

\section{Notes on contributors}

Michela Ceccorulli is Research Fellow at the University of Bologna and at the Forum on the Problems of Peace and War in Florence. She obtained her PhD at the IMT Institute for Advanced Studies in Lucca and her Master of Arts at SAIS - The Johns Hopkins University, Washington, DC. In 2014 she was within the Young Leader Programme of the Council for the United States and Italy.

Among her research interests are migration, security cooperation, and security governance. Her last publications include Framing Irregular Immigration in Security Terms: The Libya Case (Florence University Press, 2014), The EU, Migration and the Politics of Administrative Detention (with N. Labanca, Routledge, 2014), and "Multidimensional Threats and Military Engagement: The Case of the Italian Intervention in Libya" (with F. Coticchia), in Mediterranean Politics (2015).

Carlo Frappi Carlo Frappi is Research Fellow at the Department of Studies on Asia and Mediterranean Africa of Venice "Ca" Foscari" University and ISPI Associate Research Fellow at the Energy and Caucasus and Central Asia programmes. He was elected Member of the Board of Directors at Association for the Italian Study of the Central Asia and the Caucasus (ASIAC) for the triennium 2013-2015. Historian by training, between 2008 and 2010 he has been Research Fellow for the European Foreign and Security Policy Studies (EFSPS) Programme developed by Compagnia di San Paolo, Riksbankens Jubileumsfond, and Volkswagen Stiftung. His expertise covers Security cooperation in the Wider Black Sea and former Soviet area; Energy security policies and energy competition in the Eurasian space; Foreign Policy of Former Soviet Union countries; and Turkish foreign policy. Among his recent publications are the volumes "Azerbaigian, Energia per l'Europa. Storia, Economia e Geopolitica degli idrocarburi del Caspio" (Egea, Milan, 2013, co-authored with M. Verda) and "Azerbaigian. Crocevia del Caucaso" (Sandro teti Editore, Rome, 2012).

Sonia Lucarelli is Associate Professor of Political Science at the University of Bologna, where she teaches International Relations and Pan-European Security. Her main research interests include migration policy, external image of the EU, European security, European identity, and the EU in global governance. Lucarelli has vast experience in directing and coordinating research projects, with support from the EU (Globus, EU-GRASP and GARNET), NATO (PREDICT), and Italian Ministry of Foreign Affairs (Gender and the EU; Values and Principles in EU Foreign Policy). Lucarelli has given numerous invited lectures at various universities, such as Boston University, Harvard Law School, and University of Victoria (CA), and at institutions such as the European Commission and European Parliament. She is author or (co)editor of 15 books, 19 articles, 51 chapters in edited books, and two Special Issues. She has published in journals such as the Journal of European Integration, European Security, European Foreign Affairs Review, Journal of International Relations and Development, Global Affairs, and Journal of Common Market Studies.

\section{References}

Abrahamsen, R. and Leander, A., eds., 2015. Routledge handbook of private security studies. Abingdon: Routledge.

Acharya, A., 2009. Whose Ideas Matter: Agency and Power in Asian Regionalism. Cornell: Cornell University Press. 
Acharya, A., 2012. The making of Southeast Asia: international relations of a region. Oxford: Oxford University Press.

Acharya, A. and Buzan, B., eds., 2010. Non-western international relations theory: perspectives on and beyond Asia. Abingdon: Routledge.

Adler, E., 1997. Imagined (security) communities: cognitive regions in international relations. Millennium, 26 (2), 249-277.

Adler, E. and Barnett, M., 1998. Security communities. Cambridge: Cambridge University Press.

Adler, E. and Greeve, P., 2009. When security community meets balance of power: overlapping regional mechanisms of security governance. Review of Inter-national Studies, 35 (1), 59-84.

Aliyev, I., 2012. Speech by Ilham Aliyev at the fourth meeting of the heads of diplomatic service [online]. Baku, 21 September. Available from: http://en.president.az/articles/6304 [Accessed 2 September 2016].

ArNSD - National Security Strategy of the Republic of Armenia, 2007. Ministry of Foreign Affairs of Armenia [online]. Available from: http://www.mfa.am/u_files/file/doctrine/Doctrineeng.pdf [Accessed 2 September 2016].

AzNSD - National Security Concept of the Republic of Azerbaijan, 2007. Approved by Instruction No. 2198 of the President of the Republic of Azerbaijan on 23 May 2007 [online]. Available from: www. un.int/azerbaijan/pdf/National_security.pdf [Accessed 2 September 2016].

Bigo, D., 2000. When two become one. Internal and external securitizations in Europe. In: M. Kelstrup and M.C. Williams, eds. International relations, theory and the politics of European integration. London: Routledge, 320-360.

Bigo, D., 2006. Internal and external aspects of security. European Security, 15 (4), 385-404.

Boonstra, J. and Delcour, L., 2015. A broken region: evaluating EU policies in the South Caucasus [online]. Madrid: Fride Policy Brief, No. 193. Available from: http://fride.org/publication/1246/abroken-region:-evaluating-eu-policies-in-the-south-caucasus [Accessed 2 September 2016].

Börzel, T. and Risse, T., eds., 2016. The Oxford handbook of comparative regionalism. Oxford: Oxford University Press.

Bossong, R., 2008. The action plan on combating terrorism: a flawed instrument of EU security governance. Journal of Common Market Studies, 46 (1), 27-48.

Breslin, S. and Croft, S., eds., 2012. Comparative regional security governance. New York: Routledge.

Bryden, A. and Caparini, M., eds., 2006. Private actors and security governance. Zürich: LIT.

Buzan, B. and Hansen, L., 2009. The evolution of international security studies. Cambridge: Cambridge University Press.

Buzan, B. and Weaver, O., 2003. Regions and powers. Cambridge: Cambridge University Press.

Ceccorulli, M. and Lucarelli, S., 2012. Conceptualizing multilateral security governance. In: S. Lucarelli, L. Van Langenhove and J. Wouters, eds. The EU and multilateral security governance. Abingdon: Routledge, 11-25.

Ceccorulli, M. and Lucarelli, S., 2014. Security governance: making the concept fit for the analysis of a multipolar, global and regionalized world. EUI Working Papers, RSCAS 2014/41. Fiesole: Robert Schuman Centre for Advanced Studies, Global Governance Profgramme-98.

Christou, G., et al., 2010. European Union security governance: putting the "security" back in. European Security, 19 (3), 341-359.

Daase, C. and Friesendorf, D., 2010. Rethinking security governance: the problem of unintended consequences. New York: Routledge.

Deutsch, K.W., et al., 1957. Political communtiy and the North Atlantic Area: international organization in the light of historical experience. Princeton: Princeton University Press.

DeWaal, T., 2012. A broken region: the persistent failure of integration projects in the South Caucasus. Europe-Asia Studies, 64 (9), 1709-1723.

European Commission, 2001. Green paper - towards a European strategy for the security of energy supply $[\operatorname{COM}(2000)$ 769], Luxembourg, Office for Official Publications of the European Communities

Fawn, R., 2009. Regions and their study: wherefrom, what for and whereto? Review of International Studies, 35 (1), 5-34. 
Floyd, R. and Croft, S., 2010. European non-traditional security theory: from theory to practise. Geopolitics, History, and International Relations, 3 (2), 152-179.

GeNSD - National Security Concept of Georgia, 2011. Ministry of Foreign Affairs of Georgia [online]. Available from: http://www.mfa.gov.ge/index.php?lang_id=ENG\&sec_id = 12 [Accessed 2 September 2016].

Gilman, B., 1997. The silk road strategy Act of 1997, H.R. 2867, Congressional Record, vol. 143, Issue 156, US Government Printing Office, Washington, November

Gwi-Ok, K., 2013. Building a peaceful East Asian community: origins of a regional concept and visions for a global age. Asian Perspective, 37 (2), 233-254.

Hallenberg, J., Sperling, J., and Wagnsson, C., eds., 2009. European security governance. The European Union in a Westphalian World. Abingdon: Routledge.

Hemmer, M.C. and Katzenstein, P.J., 2002. Why there is no NATO in Asia? Collective identity, regionalism, and the origins of multilateralism. International Organization, 56 (3), 575-607.

Hooghe, L. and Marks, G., 2003. Unraveling the central state. But how? Types of multilevel governance. American Political Science Review, 97 (2), 233-243.

Kacowicz and Galia Press-Barnathan, 2016. Regional security governance. In: T. Börzel and T. Risse, eds. The Oxford handbook of comparative regionalism. Oxford: Oxford University Press, 297-322.

Kaunert, C. and Léonard, S., eds., 2013. European security governance and the European neighbourhood after the Lisbon treaty. Abingdon: Routledge.

Kirchner, E.J. and Dominguez, R., eds., 2011. The security governance of regional organizations. London: Routledge.

Kirchner, E.J. and Sperling, J., 2007. EU security governance. Manchester: Manchester University Press. Krahmann, E., 2003. Conceptualizing security governance. Cooperation and Conflict, 38 (1), 5-26.

Krahmann, E., ed., 2005. New threats and new actors in international security. Basingstoke: Palgrave MacMillan.

Krahmann, E., 2010. States, citizens and the privatization of security. Cambridge: Cambridge University Press.

Leander, A., 2006. The market for force and public security: the destabilizing consequences of private military companies. Journal of Peace Research, 42 (5), 605-22.

Lucarelli, S., Pinfari, M., and Hanau Santini, R., 2013. Inter-regionalism: a security studies perspective. In: F. Söderbaum, F. Baert, and T. Scaramagli, eds. Intersecting Inter-regionalism. Dordrecht: Springer, 71-88.

Lucarelli, S., Van Langenhove, L., and Wouters, J., eds., 2012. The EU and multilateral security governance. Routledge: Abingdon.

Ministry of Foreign Affairs of the Russia Federation, 2013. Concept of the foreign policy of the Russian Federation [online]. Available from: http://archive.mid.ru//brp_4.nsf/0/76389FEC168189ED 44257B2E0039B16D [Accessed 2 September 2016].

NATO, 2005. Water - a key security asset [online]. Belgium: NATO Public Diplomacy Division. Available from: http://www.nato.int/docu/water/water-e.pdf [Accessed 2 September 2016].

Paasi, A., 2009. The resurgence of the "region" and "regional identity": theoretical perspectives and empirical observations on regional dynamics. Review of International Studies, 35 (1), 121-146.

Pashayev, H., 2009. Azerbaijan-US relations: from unjust sanctions to strategic partnership. In: F. Ismailzade and A. Petersen, eds. Azerbaijan in global politics. Crafting foreign policy. Baku: Azerbaijan Diplomatic Academy, 109-129.

Republic of Turkey, 2012. Trabzon Declaration of the Ministers of Foreign Affairs of the Republic of Azerbaijan, Georgia and the Republic of Turkey [online]. Trabzon: Ministry of Foreign Affairs. 8 June. Available from: http://www.mfa.gov.tr/trabzon--declaration-of-the-ministers-of-foreignaffairs-of-the-republic-of-azerbaijan_-georgia-and-the-republic-of-turkey_-08-june-2012_-trabzon. en.mfa [Accessed 2 September 2016].

Semneby, P., 2006. The role of the EU in the resolution of conflicts in the South Caucasus. Turkish Policy Quarterly, 5 (2), 17-20.

Sperling, J., 2009. Security Governance in a Westphalian World. In: J. Sperling, C. Wagnsson, and J Hallenberg, eds. European Security Governance. The European Union in a Westphalian World. London: Routledge. 
Sperling, J., 2012. The Post-Westphalian State, National Security Cultures, and Global Security Governance. In: S. Lucarelli, L. Van Langenhove, and J. Wouters, eds. The EU and multilateral security governance. Abingdon: Routledge, 26-42.

Sperling, J., ed., 2014. Handbook of governance and security. Cheltenham: Edward Elgar Publishing. Sperling, J. and Webber, M., 2014. Security governance in Europe: a return to system. European Security, 23 (2), 126-144.

Steele, B.J., 2008. Ontological security in international relations: self identity and the IR State. New York: Routledge.

The White House. 1997. A national security strategy for a new century. Washington, DC: US Government Printing Office.

Wæver, O., 2004. New "schools" in security theory and their origins between core and periphery. Paper presented at the annual conference of the International Studies Association. Montreal, Canada.

Westermeyer, G., 2013. The impact of private actors on security governance. Unterschleissen: Springer. 